ISSN (Print) : 1412-7601

ISSN (Online) : 2654-8712

Volume 7, No.2 September 2021

EKONOBIS

\title{
Model Partisipasi Masyarakat Lokal Dalam Ekowisata Mangrove di Desa Lembar Selatan, Kecamatan Lembar, Kabupaten Lombok Barat
}

\section{Emi Salmah, Titi Yuniarti, Endang Astuti, Eka gustiani, Siti Fatimah.}

Universitas Mataram

\begin{tabular}{l}
\hline A R T I C LE I N F O \\
\hline Keywords: \\
Community Participation \\
Model, Mangrove Eco- \\
tourism, South Sheet
\end{tabular}

Kata Kunci:

Model Partisipasi

Masyarakat, Ekowisata

Mangrove, Lembar

Selatan
ABSTRACT : Community participation in tourism activities is an activity carried out entirely by the community. The idea of activities and management is carried out entirely by the community in a participatory manner, and the benefits are felt directly by the local community.

This study aims to 1) Formulating a model for local community participation in Mangrove Ecotourism in South Lembar Village, Kec. Lembar, West Lombok Regency, 2) Analyzing how they manage information as part of local community participation in Mangrove ecotourism in South Lembar Village, Kec. Lembar, West Lombok Regency. The type of research used is descriptive with quantitative and exploratory approaches. Using primary data and secondary data, data collection methods, observation, in-depth interview and literature review. The collected data will be analyzed and calculated using the Excel system, then presented in the form of frequency tables and bar charts.

The results show that many people have participated in mangrove ecotourism in South Lembar Village, by opening a culinary business (Sasak specialties), renting canoes/boats to surround the mangrove location, parking services involving the community, especially young people, selling and checking entrance tickets. In disseminating information, it has been carried out by teenagers who are members of the South Lembar Village Youth Organization. The community participation model in managing information must have a collective will (community, village officials, government and private sector) in developing South Lembar Mangrove ecotourism significantly.

ABSTRAK: Partisipasi masyarakt dalam kegiatan pariwisata merupakan suatu kegiatan yang dilakukan sepenuhnya oleh masyarakat. Ide kegiatan dan pengelolaan dilakukan seluruhnya oleh masyarakat secara partisipatif, dan manfaatnya dirasakan langsung oleh masyarakat lokal.

Penelitian ini bertujuan untuk 1) Merumuskan Model partisipasi masyarakat lokal dalam Ekowisata Mangrove di Desa Lembar Selatan, Kec. Lembar Kabupaten Lombok Barat, 2) Menganalisis bagaimana mereka mengelola informasi sebagai bagian dari partisipasi masyarakat lokal dalam ekowisata Mangrove di Desa Lembar Selatan, Kec. Lembar Kabupaten Lombok Barat. Jenis penelitian yang digunakan adalah Diskriptif dengan pendekatan kuantitatif dan eksploratif. Menggunakan data primer dan data Sekunder, metode pengumpulan data, observasi, Wawancara secara mendalam (indepth interview) dan telaah pustaka. Data yang terkumpul akan dianalisa dan dihitung dengan menggunakan system Excel, lalu disajikan dalam bentuk tabel frekuensi dan diagram batang.

Hasil penelitian menunjukkan bahwa masyarakat sudah banyak yang berpartisipasi dalam ekowisata mangrove di Desa Lembar Selatan, dengan membuka usaha kuliner (makanan khas Sasak), menyewakan sampan/perahu untuk mengelilingi lokasi mangrove, jasa parkir yang melibatkan masyarakat khususnya anak muda, menjual dan memeriksa tiket masuk. Dalam penyebaran informasi, sudah dilakukan oleh para remaja yang tergabung dalam Karang Taruna Desa Lembar Selatan. Model partisipasi masyarakat dalam mengelola informasi harus ada kemauan secara bersama-sama (masyarakat, aparat desa, pemerintah dan swasta) dalam mengembangkan ekowisata Mangrove Lembar Selatan secara signifikan. 
Corresponding Author :

Alamat : Program Studi Ekonomi Pembangunan, Fakultas Ekonomi dan Bisnis, Universitas Mataram, Jln. Majapahit No. 62 Mataram.

e-mail: emisalmah0101@gmail.com

2021, EKONOBIS All right reserved

\section{PENDAHULUAN}

\section{Latar Belakang}

Pariwisata sebagai suatu aktivitas, adalah fenomena sosial yang sangat kompleks dan menyatu dalam segala aspek kehidupan manusia. Pariwisata merupakan keseluruhan kegiatan untuk penataan dan pelayanan terhadap pemenuhan kebutuhan berwisata, sehingga memiliki dampak yang besar sekali terhadap sistem nilai masyarakat, baik dampak yang bersifat positif maupun dampak yang bersifat negatif (Ade Jafar Sidiq, dkk 2016). Provinsi Nusa Tenggara Barat (NTB) merupakan salah satu daerah Destinasi wisata di Indonesia yang telah dikunjungi oleh banyak wisatawan baik dalam negeri maupun luar negeri. Provinsi NTB terdiri dari dua (2) Pulau yakni P. Lombok dan P. Sumbawa mempunyai banyak obyek wisata yang menarik untuk dikunjungi, tersebar pada 10 (sepuluh) kabupaten/Kota yang ada di NTB. Salah satunya adalah di Kabupaten Lombok Barat, beberapa obyek wisata yang ada antara lain; pantai, cagar budaya, Gili, pegunungani dan ekowisata.

Salah satu ekowisata yang terdapat di Kabupaten Lombok Barat adalah Ekowisata Alam Mangrove yang terletak di Pantai Cemara, Desa Lembar Selatan Kecamatan Lembar Kabupaten Lombok Barat. Ekowisata mangrove ini memiliki potensi wisata alam yang indah dan pemandangan yang menarik.

Diperkenalkannya Ekowisata Mangrove sebagai salah satu tujuan wisata yang berbasiskan masyarakat di Desa Lembar
Selatan ini, membawa implikasi terhadap pemanfaatan aspek spasial (kewilayahan /geografi) untuk pariwisata. Aspek spasial yang dimaksud di sini adalah sumberdaya geografi pantai dan perdesaanya serta aspek sosial yang berkenaan dengan motivasi kedatangan wisatawan, motivasi masyarakat setempat (ekonomi dan budaya) dan industri pariwisata.

Berkembangnya usaha jasa pariwisata yang dikelola oleh masyarakat setempat di kawasan ekowisata mangrove dalam bentuk, akomodasi (warung makan/ minum, jasa parkir dan tempat foto/ hotspot yang menarik), jasa penyedia perahu untuk mengelilingi area wisata mangrove, merupakan sebuah bukti nyata tentang sebuah bentuk pariwisata yang berbasiskan masyarakat. Selain partisipasi masyarakat dalam usaha jasa pariwisata yang disebutkan di atas penting juga untuk mengetahui partisipasi masyarakat dalam informasi pariwisata di kawasan ekowisata mangrove.

Pariwisata berbasis masyarakat merupakan model pembangunan yang memberikan peluang yang sebesarbesarnya kepada masyarakat pedesaan untuk berpartisipasi dalam kegiatan pariwisata. Partisipasi masyarakt dalam kegiatan pariwisata merupakan sebuah kegiatan yang dilakukan sepenuhnya oleh masyarakat. Ide kegiatan dan pengelolaan dilakukan seluruhnya oleh masyarakat secara partisipatif, dan manfaatnya dirasakan langsung oleh masyarakat lokal. Dengan demikian, peran masyarakat lokal 
sebagai pemangku kepentingan merupakan unsur terpenting dalam pengembangan wisata (Titi Yuniarti dkk, 2018).

Namun demikian sebagai tujuan wisata yang relatif baru dan belum terlalu dikenal di Kabupaten Lombok Barat, sampai saat ini belum diketahui bentuk dan tingkat partisipasi masyarakat setempat dalam informasi pariwisata di kawasan ekowisata Mangove sebagai model pariwisata yang berbasiskan masyarakat. Hal ini disebabkam belum teridentifikasikannya bentuk partisipasi masyarakat setempat menjadi penyebab keadaan tersebut. Berdasarkan keterangan di atas maka penelitian ini disusun untuk mengidentifikasi model partisipasi masyarakat lokal dalam kegiatan wisata di kawasan ekowisata Mangrove.

Hasil Survei awal menunjukkan bahwa partisipasi masyarakat lokal sekarang masih terbatas pada penyediaan warung makan/minum dan jasa sampan/perahu, sedangkan partisipasi dalam hal informasi belum banyak.

Berdasarkan permasalahan tersebut perlu dilakukan suatu penelitian tentang "Model Partisipasi Masyarakat Lokal dalam Ekowisata Mangove di Pantai Cemara, Kecamatan Lembar Kabupaten Lombok Barat".

\section{Rumusan Masalah}

1. Bagaimana model partisipasi masyarakat lokal dalam Ekowisata Mangrove di Pantai Cemara, Lembar Kabupaten Lombok Barat.

2. Bagaimana mengelola informasi sebagai bagian dari partisipasi masyarakat lokal dalam ekowisata Mangrove. di Pantai Cemara, Lembar Kabupaten Lombok Barat.

\section{Tujuan Penelitian}

1. Merumuskan model partisipasi masyarakat lokal dalam ekowisata Mangrove di Pantai Cemara, Kabupaten Lombok Barat.

2. Menganalisis cara mengelola informasi sebagia bagian dari partisipasi masyarakat lokal dalam ekowisata Mangrove di Pantai Cemara Kec. Lembar, Lombok Barat.

\section{KAJIAN PUSTAKA}

\section{Pengertian Umum Pariwisata}

Istilah pariwisata berasal dari dua suku kata, yakni pari dan wisata. Pari berarti banyak, berkali-kali atau berputar-putar. Wisata berarti perjalanan atau bepergian. Jadi pariwisata adalah perjalanan atau bepergian yang dalam hal ini sinonim dengan kata "travel" dalam bahasa Inggris. Atas dasar itu, maka kata "pariwisata" dapat diartikan sebagai perjalanan yang dilakukan berkali-kali atau berputar-putar dari suatu tempat ke tempat yang lain (Yoeti, A. O. 1982., dalam Soekadijo, 2000). UU. No 10 Tahun 2009 tentang Kepariwisataan dalam Ade Jafar Sidiq (2016) menjelaskan bahwa pariwisata adalah berbagai macam kegiatan wisata yang didukung oleh berbagai fasilitas serta layanan yang disediakan masyarakat, pengusaha, Pemerintah dan Pemerintah Daerah.

Menurut Oka A. Yoeti (1982) Wisata adalah suatu perjalanan yang dilakukan sementara waktu, yang diselenggarakan dari satu tempat ke tempat lain dengan maksud bukan untuk berusaha (bisnis) atau mencari nafkah di tempat yang dikunjungi, tetapi semata- mata untuk menikmati perjalanan tersebut guna pertamasyaan dan rekreasi atau untuk 
memenuhi keinginan yang beraneka ragam, sedangkan pariwisata juga berarti perpindahan orang untuk sementara dan dalam jangka waktu pendek ke tujuantujuan di luar tempat dimana mereka biasanya hidup dan bekerja, dan kegiatankegiatan mereka selama tinggal di tempattempat tujuan tersebut (Soekadijo, 2000:3).

WTO memberi defenisi sebagai berikut :

1. Pengunjung adalah setiap orang yang berkunjung ke suatu Negara lain dimana ia mempunyai tempat kediaman, dengan alasan melakukan pekerjaan yang diberikan oleh Negara yang dikunjunginya.

2. Wisatawan adalah setiap orang yang bertempat tinggal di suatu Negara tanpa memandang kewarganegaraanya, berkunjung ke suatu tempat pada Negara yang sama dalam jangka waktu lebih dari 24 jam yang tujuan perjalannya dapat diklasifikasikan pada salah satu hal berikut ini:

a. Memanfaatkan waktu luang untuk berekreasi, liburan, kesehatan, pendidikan, keagamaan, dan olahraga.

b. Bisnis atau mengunjungi kaum keluarga, rapat, bisnis, atau misi tertentu

3. Darmawisata atau excursionist adalah pengunjung sementara yang menetap kurang dari 24 jam di negara yang dikunjunginya termasuk orang yang berkeliling dengan kapal pesiar, namun tidak termasuk para pesiar yang memasuki negara legal, contohnya orang yang hanya tinggal di ruang transit pelabuhan udara (Amran, Amir Muh., 2017).
Di Indonesia, pengertian wisatawan tercantum dalam Instruksi Presiden RI No. 9 tahun 1969, yaitu setiap orang yang berpergian dari tempat tinggalnya untuk berkunjung ke tempat lain dengan menikmati perjalanan dan kunjungan itu.

Wisata berasal dari kata sansekerta yang berarti perjalanan, maksudnya kegiatan yang dilakukan untuk memenuhi kebutuhan fisik atau untuk bersosialisasi dan interaksi yang lebih mendalam agar dapat lebih membutuhkan pemahaman dan penghargaan terhadap daerah yang dikunjungi.

\section{Jenis Pariwisata}

Berdasarkan penentuan obyek/tujuan obyek wisata jenis dan tempat obyek wisata dibedakan atas: Wisata Alam, Wisata Budaya, Wisata Remaja, Wisata pendidikan, Wisata Petualangan, Wisata Leasure

Wisata Sosial Budaya dan Agrowisata, yaitu Wisata yang mengunjungi tempattempat perkebunan yang khas, menikmati romantisnya suasana pedesaan dan kawasan-kawasan pertanian tradisional, atau tempat pendayagunaan unsur pertanian seperti perikanan peternakan. Wisata ini juga dapat terkait dengan wisata pendidikan atau sosial budaya.

\section{Pentingnya Partisipasi Masyarakat}

Pada umumnya sejumlah kalangan sepakat perlu dikembangkan partisipasi sebagai upaya menyertakan masyarakat seluasluasnya yang mendorong, berkembangnya proses kebersamaan. Munculnya proses partisipasi dalam rangka pemberdayaan masyarakat mendasarkan atas dua pendekatan, yaitu:

1. Pelibatan masyarakat dalam pemilihan, perancangan, perencanaan dan pelaksanaan program, sehingga dengan demikian adanya jaminan pola 
sikap dan pola pikir serta nilai-nilai dan pengetahuannya ikut dipertimbangkan.

2. Membuat umpan balik yang pada hakikatnya merupakan bagian yang tidak terlepaskan dari kegiatan pembangunan. (Ade Jafar Sidiq, dkk 2016)

Miller (1999), mengidentifikasi ada dua penggunaan partisipasi yaitu sebagai tujuan pada dirinya sendiri dan sebagai alat mengembangkan diri. Keduanya merupakan satu kesatuan yang satu bersifat partisipasi transformasional dan yang lain bersifat partisipasi instrumental. Dalam pembinaan pemberdayaan masyarakat dibidang pariwisata. Kedua bentuk partisipasi tersebut baik transformasional dan instrumental perlu dikembangkan, mengingat pada tahap transformasional, partisipasi masyarakat dibutuhkan dalam membentuk gagasan besar yang mampu menggalang kesadaran untuk perubahan dalam pembangunan kebudayaan dan kepariwisataan, mengingat pembangunan kepariwisataan memiliki titik singgung multidimensional yang keberhasilan pembangunannya banyak mengandalkan hasil dari sektor pembangunan lainnya. Disamping itu pengayaan kesadaran dan tanggung jawab bersama merupakan upaya yang harus terus digalang sebagai penggerak proses partisipasi.

\section{Model Partisipasi Masyarakat dalam Pariwisata}

Partisipasi masyarakat dapat juga diartikan sebagai keikutsertaan, keterlibatan dan kebersamaan anggota masyarakat dalam keadaan tertentu, baik secara langsung seperti tenaga pada kegiatan lapangan. Sedangkan partisipasi tidak langsung seperti pemikiran, dana dan materi (Pratiwi, 2007, dalam Titi Y dkk 2018). Untuk menindaklanjuti prinsip partisipasi masyarakat seperti yang dijelaskan di atas maka dalam penelitian ini partisipasi masyarakat setempat dalam pariwisata di Kawasan ekowisata Mangrove akan mengarah pada indikator pelibatan unsur kelompok yang terlibat (World Tourism Organization, 2004) yang terdiri:

1. Masyarakat setempat.

2. Sektor Pemerintah,

3. Sektor Swasta,

4. LSM,

5. Wisatawan

World Tourism Organization (2004) juga memberikan penekanan tentang kelompok masyarakat setempat yang akan terlibat dalam kegiatan pariwisata, yang terdiri dari:

1. Kelompok masyarakat setempat

2. Kelompok masyarakat dan budaya

3. Pekerja sektor swasta (tenaga kerja lokal)

4. Pemilik aset lokal

5. Kelompok usaha

Dengan demikian asset dan tenaga kerja mejadi fokus partisipasi masyarakat setempat dalam pariwisata di Kawasan Ekowisata Mangrove.

Lebih lanjut, De Soto (2000), dalam Ade Jafar Sidiq, dkk (2016) memberikan penegasan tentang keberpihakan pada asset atau modal dan tenaga kerja dalam bentuk sektor informal pada masyarakat setempat di negara berkembang. Sektor informal adalah pengelolaan kegiatan ekonomi yang dikelola oleh masyarakat dalam skala kecil namun tidak terkena pajak pemerintah. Namun demikian, sektor informal bukanlah sesuatu yang bersifat kriminal (tidak dikenakan pajak). 
WTO (2004) menyatakan bahwa partisipasi masyarakat juga dilakukan dalam bentuk ketersediaan informasi berkaitan dengan kegiatan pariwisata di sebuah kawasan wisata dengan keterangan sebagai berikut:

1. Ketersediaan informasi,

2. Akses pada informasi,

3. Analisa informasi,

4. Penerapan informasi,

5. Dukungan terhadap informasi dan

6. Penerapan dampak pada informasi. (Marpaung, H, 2000).

\section{Konservasi Mangrove}

Menurut Asisten I Menteri Negara KLH pada tesis Saptorini, yang dimaksud dengan konservasi adalah pengelolaan biosfer bagi keperluan manusia sehingga menghasilkan manfaat sebesar-besarnya bagi generasi kini dan memantapkau potensi untuk memenuhi kebutuhan dan aspirasi generasi yang akan datang. Konservasi mencakup pengawetan, perlindungan, pemanfaatan secara lestari, rehabilitasi dan peningkatan umum lingkungan alam. Sudah diketahui bahwa komunitas mangrove merupakan salah satu sistem penyangga kehidupan. Berdasarkan berbagai peraturan, kerusakan hutan mangrove sebagai akibat tindakan manusia maupun karena faktor alam harus segera ditanggulangi dengan upaya konservasi sebagaimana diisyaratkan oleh peraturan-peraturan (Laksmi Puja Sukma, 2018).

Menurut Hendrarto dalam merehabilitasi kawasan mangrove pada hakekatnya yang perlu diperhatikan adalah:

1. sifat tumbuhan penyusun hutan mangrove,

2. ketersediaan lumpur,

3. tekstur tanah dan

4. pasang surut.
Selanjutnya dijelaskan bahwa pemilihan jenis mangrove yang digunakan dalam program penghijauan pantai biasanya tergantung pada faktor-faktor:

1. kemudahan dalam memperoleh bibit,

2. mempunyai kecepatan pertumbuhan yang tinggi dan

3. mempunyai daya toleransi tinggi terhadap rnanipulasi habitat.

Karena pada umunmya yang memenuhi krìteria ini adalah jenis dan marga Rhizophora, maka jenis ini dipergunakan dalam program penghijauan (Laksmi Puja Sukma, 2018).

\section{Ekowisata di Indonesia}

Ekowisata atau Ekoturisme merupakan salah kegiatan pariwisata yang berwawasan lingkungan dengan mengutamakan aspek konsevasi alam, aspek pemberdayaan sosial budaya ekonomi masyarakat lokal dan aspek pembelajaran dan pendidikan.

Pada awalnya ekowisata dijalankan dengan membawa wisatawan ke obyek wisata alam yang eksotis dengan cara ramah lingkungan. Proses kunjungan yang sebelumnya memanjakan wisatawan, namun memberi dampak negatif kepada lingkungan mulai dikurangi.

Di Indonesia kegiatan ekowisata mulai dirasakan pada pertengahan Tahun 1980an, dimulai atau dilaksanakan oleh orang atau biro wisata asing. Salah satu dari proyek ekowisata yang terkenal yang dikelola pemerintah adalah ekowisata yang dikelola pemerintah bersama dengan lembaga Asing adalah ekowisata orang hutan di Tanjung Puting, Kalimantan. Kegiatan ekowisata di Indonesia diatur Peraturan Menteri Dalam Negeri no 33 Tahun 2009. 
Secara umum obyek kegiatan ekowisata tidak jauh berbeda dengan kegiatan wisata alam biasa, tetapi memiliki nilai nilai moral dan tanggung jawab yang tinggi terhadap obyek wisatany. Kegiatan Ekowisata lain adalah:

a. Wisata Pemandangan, (obyek-obyek alam, Flora, Fauna).

b. Wisata Petualangan (Kegiatan alam bebas, kegiatan ekstrim dan berburu)

c. Wisata Kebudayaan dan sejarah (Suku terasing, Kerajinan tangan, peninggalan bersejarah)

d. Wisata Penelitian (Pendataan species, Pendataan kerusakan alam dan konservasi)

e. Wisata sosial, konservasi dan penelitian.

\section{Penelitian Terdahulu}

Sebelum melakukan penelitian ini, telah dipelajari penelitian terdahulu yang relevan. Penelitian terdahulu menjadi acuan dalam melakukan penelitian, sehingga dapat memperkaya teori dalam mengkaji penelitian yang dilakukan. Beberapa penelitian yang menjadi acuan dan bahan penelitian adalah:

Penelitian yang dilakukan oleh Arief Faizal Rahman (2014) dengan judul "Model Partisipasi Masyarakat Daklam Pariwisata di Pantai Swarna Kabupaten Lebak, Provinsi Banten". Menggunakan alat analisis diskriptif, lalu ditarik kesimpulan dengan menganalisa kajian teoritis atau tinjauan pustaka. Hasil penelitian tersebut, 1) Bahwa model partisipasi masyarakat dalam mengelola informasi dan kemauan secara bersama untuk mengembangkan pariwisata dikawasan ini secara signifikan terlaksana. 2) Inisiasi yang dilakukan oleh masyarakat dalam kegiatan pariwisata telah memenuhi bahkan melampaui target pemerintah dalam pencapain Pendapatan Asli Daerah ( PAD ) melalui tiket masuk. Penelitian yang dilakukan oleh Maria Grace Lawe Siu, dkk di Kota Kupang, Tahun 2020.. Penelitian ini menggunakan metode deskriptif kualitatif melalui penyebaran kuisioner kepada pihak terkait dan kemudian dikaji secara kuantitatif untuk menunjukkan nilai nyata. Hasil penelitian menunjukkan tingkat partisipasi masyarakat dalam pengelolaan ekowisata mangrove guna mengembangkan kawasan ekowisata di Kelurahan Oesapa Barat sangat rendah. Dukungan dari pengelola dibutuhkan oleh semua pihak terkait untuk memberikan pengetahuan dan kepedulian agar program pengembangan ekowisata Kelurahan Oesapa Barat dapat berjalan sesuai harapan.

Penelitian lain yang dilakukan oleh Titi $Y$, dkk Tahun 2019 dengan judul " Partisipasi Masyarakat Lokal dalam Pengembangan Agrowisata di Kecamatan Gangga Kabupaten Lombok Utara". Menggunakan alat analisa diskripsi. Hasil penelitian menunjukkan bahwa, 1) Masyarakat belum banyak berpartisipasi dalam perencanaan dan pengawasan, 2) Masyarakat sudah berpartisipasi/ mengambil peran yang besar dalam menyediakan sarana dan prasaran seperti penginapan (villa), warung warung yang menjual makanan/minuman khas lokal, Kios yang menyediakan pulsa elektrik, warung yang menjual palen-palen, menanam tanaman melon organik selain tanaman buah yang sudah ada, 3) Menyediakan jasa antar/guest bagi wisata Mancanegara.

\section{METODOLOGI PENELITIAN}

\section{Metode dan Unit Analisis Penelitian}

Metode penelitian yang digunakan adalah metode deskriptif dengan pendekatan 
kuantitatif dan eksploratif. Penelitian ini, lebih memfokuskan pembahasan mengenai Model Partisipasi Masyarakat lokal dalam ekowisata mangrove. Unit analisis yaitu unit yang diamati dan dijelaskan, serta merupakan objek penelitian yang dapat berupa individu/ perorangan, kelompok organisasi, masyarakat, hasil karya manusia, instansi dan sebagainya (Kusmayadi, 2000:29). Sehingga, didalam penelitian ini, unit analasis yang diamati adalah model partisipasi masyarakat lokal (pada informasi) dalam pariwisata di Kawasan ekowisata mangrove di Desa Lembar Selatan, Kecamatan Lembar, Lombok Barat.

\section{Metode Pengumpulan Data}

Metode pengumpulan data yang digunakan adalah:

1. Wawancara,

2. Observasi dan

3. Telaah Pustaka

\section{Prosedur Penarikan Sampel}

Objek penelitian yang menjadi populasi dalam penelitian ini adalah pihak-pihak yang terkait dengan partisipasi masyarakat dalam Ekowisata mangrove, seperti instansi terkait antara lain, Dinas Pariwisata Kab. Lombok Barat, Kepala Desa dan stafnya, masyarakat umum, tokoh masyarakat, Kelompok Sadar Wisata (Pokdarwis) dan pengelola jasa usaha wisata. Masing masing pihak ini akan diambil 5 orang sebagai sampel, sehingga keseluruhan responden berjumlah 30 orang yang diharapkan dapat mewakili dan repsresentatif untuk mendapatkan infomasi guna tercapainya tujuan penelitian.

\section{Variabel - Variabel}

Variabel yang dapat membantu pada penelitian ini antara lain.
1. Variabel Demografi: Usia, pendidikan dan Pekerjaan,

2. Variabel Model Partisipasi Masyarakat: ketersediaan informasi, akses pada informasi, analisa informasi, penerapan informasi, dukungan informasi dan dampak informasi.

\section{Metode Analisis Data}

Data diperoleh dari hasil wawancara menggunakan kuisioner yang berisikan sejumlah pertanyaan. Data tersebut dikumpulkan dan diolah dengan menggunakan analisis deskriptif, lalu ditarik kesimpulan dengan menganalisa kajian teoritis atau tinjauan pustaka sehingga memberikan gambaran bagaimanakah Model partisipasi masyarakat lokal dalam Ekowisata mangrove di Desa Lembar Selatan, Kecamatan Lembar, Kabupaten Lombok Barat. Data yang terkumpul akan dianalisa dan dihitung dengan menggunakan system Excel, lalu disajikan dalam bentuk tabel frekuensi serta disajikan juga nilai rata-rata dari indikator yang sudah ditetapkan.

HASIL DAN PEMBAHASAN

\section{Gambaran Umum Lokasi Penelitian.}

Kecamatan Lembar merupakan salah satu dari sepuluh Kecamatan yang ada di Kabupaten Lombok Barat. Kecamatan Lembar memiliki sepuluh desa, yakni: Desa Mareje, Sekotong Timur, Lembar, Jembatan Kembar, Labuan Tereng, Mareje Timur, Lembar Selatan, Jembatan Gantung, Jembatan Kembar Timur dan Desa Eyat Mayang. Luas wilayah Kecamatan Lembar adalah 77, 19 km2 atau sekitar $15 \%$ dari luas wilayah Kabupaten Lombok Barat (Kecamatan Lembar dalam Angka Tahun 2020).

\section{Penduduk}

Kecamatan Lembar termasuk kecamatan yang memiliki jumlah penduduk yang 
padat di Kabupaten Lombok barat. Berdasarkan hasil pendataan penduduk di Kecamatan Lembar pada tahun 2019 tercatat penduduk sebanyak 51.407 jiwa dengan kepadatan penduduk sebanyak 666 jiwa per km2.

\section{Sarana Penunjang Pariwisata}

\section{a. Sarana Komunikasi}

Kecamatan Lembar sudah terlayani berbagai macam alat komunikasi antara lain Kantor Pos pembantu, TV, Radio/tape dan telpon. Sedangkan jaringan telekomunikasi berupa jaringan telpon selular sudah merata diseluruh desa. Alat komunikasi yang lain seperti Radio/tape dan TV hampir merara diseluruh desa, sementara telfon rumah hanya ada di Desa Lembar dan Jembatan Kembar.

Sarana komunikasi atau jaringan telepon yang ada di Kecamatan Lembar sudah cukup memadai karena hampir semua desa terlayani jaringan telpon (terutama selular), siaran TV, siaran Radio, dII).

\section{b. Aksesibilitas}

\section{Kualitas Jalan}

Kecamatan Lembar mempunyai panjang jalan $\pm 155 \mathrm{~km}$, dengan kondisi permukaan jalan yang terdiri dari aspal, diperkeras, dan tanah. Total panjang jalan aspal yaitu $115 \mathrm{~km}$, total panjang jalan diperkeras yaitu $35 \mathrm{~km}$, sedangkan total panjang jalan tanah adalah $5 \mathrm{~km}$.

Jalan yang diaspal panjangnya lebih kurang $115 \mathrm{~km}$ atau 74,19 persen dari keseluruhan jalan di Kecamatan Lembar. Jalan yang diperkeras sepanjang $35 \mathrm{Km}$ atau 22,59 persen, sedangkan jalan tanah sepanjang 5 $\mathrm{Km}$ atau 3,22 persen (Kecamatan Lembar dalam Angka Tahun 2019).

2. Jenis Angkutan

Angkutan yang banyak terdapat di Kecamatan Lembar adalah mobil, sepeda motor, dan kapal. Terbanyak dimiliki oleh masyarakat adalah kendaraan roda dua, disusul oleh roda empat.

\section{Sosial dan Budaya Masyarakat}

Masyarakat yang mendiami wilayah Kecamatan Lembar merupakan penduduk asli (Suku Sasak) dan menggunakan bahasa Sasak sebagai bahasa pengantar seharihari. Ditinjau dari aspek sosial budaya atau adat istiadat masyarakat Kecamatan Lembar masih erat atau kental dengan adat Sasak terlebih pada pesta perkawinan yang masih menggunakan aturan dan ketentuan adat Sasak walaupun sedikit banyaknya modernisasi telah mempengaruhi masyarakat yang dapat kita lihat dari cara berpakaian sehari-hari utamanya pada pemuda. Ini membuktikan bahwa masyarakat menerima atau terbuka terhadap hal-hal yang baru. Dalam menjalankan aktifitas sehari-hari, masyarakat setempat dikenal sebagai masyarakat pekerja keras serta semangat kegotong-royongan atau tingkat partisipasi masyarakat yang tinggi dan ramah.

\section{Aspek Kunjungan Wisatawan}

Jumlah wisatawan yang berkunjung di lokasi kawasan wisata sangatlah penting dalam usaha pengembangan, diversifikasi obyek wisata dan daya dukung obyek. Oleh karena itu dibutuhkan data jumlah kunjungan wisatawan pada obyek wisata tersebut sehingga dapat diprediksikan kecenderungan (trend) yang muncul juga dampak negative yang akan ditimbulkan oleh wisatawan terhadap obyek dan daya dukungnya.

Jumlah wisatawan yang melakukan kunjungan di lokasi kawasan tersebut dari tahun ke tahun tidak ada catatan yang pasti, tapi tetap ada tiap hari apa lagi pada hari minggu, libur nasional, hari raya dan mengalami peningkatan. Ini kemungkinan meningkatnya minat masyarakat untuk 
menikmati wisata alam, mencari udara segar sambil naik perahu mengelilili lokasi mangrove dan lokasinya mudah terjangkau dan dekat.

\section{Fasilitas Rekreasi}

Fasilitas rekreasi yang ada di Kecamatan Lembar belum memadai sebab sarana yang terdapat di kecamatan ini hanya berupa objek wisata pantai tanpa ada sarana penunjang lainnya seperti bioskop / teater, hotel dan restoran yang besar dan taman hiburan dan lainnya. Selain itu sarana rekreasi yang ada di kecamatan ini belum memiliki dampak yang signifikan terhadap perekonomian masyarakat setempat sebab sarana tersebut tidak dikelola dengan baik oleh pemerintah sehingga masyarakat yang berkunjung ke tempat tersebut hanya sedikit. Jadi perlu diadakan sarana penunjang wisata lainnya dan juga pengelolaan yang baik terhadap objek wisata yang ada.

\section{Karakteristik Responden}

Dalam membahas karakteristik responden, akan dibahas masalah umur, pendidikan, pekerjaan dan jumlah Tanggungan.

\section{a. Umur.}

Umur merupakan salah satu faktor yang berpengaruh terhadap kemampuan manusia untuk bekerja secara fisik maupun mental guna memenuhi kebutuhan hidupnya. Rata rata umur Responden yang diwawancara dalam penelitian ini 44,68 atau 45 tahun dengan kisaran umur 25-60 tahun. Dengan umur yang terbanyak adalah $40-49$ tahun sebanyak 16 orang atau 38,09 persen dan yang paling sedikit responden dengan kisaran umur di bawah 30 dan di atas 60 tahun.

Memperhatikan umur tersebut para responden ini termasuk dalam kelompok umur produktif, yang berarti responden sebagai kepala keluarga secara fisik mental mempunyai kemampuan untuk menghasilkan barang dan jasa khususnya dalam mempromosikan wisata alam mangrove dan berusaha dalam mendukung wisata ini sedemikian rupa agar lebih berkembang lagi.

\section{b. Tingkat Pendidikan Responden}

Tingkat pendidikan berhubungan erat dengan kemampuan responden dalam menentukan usaha dan apa bentuk keterlibatan mereka dalam kegiatan pengembangan pariwisata ekowisata mangrove di Desa Lembar Selatan.

Hasil penelitian menunjukkan bahwa sebagian besar responden yang terlibat dalam usaha wisata mangrove berpendidikan tidak tamat SMA (TT SMA) berjumlah 15 orang atau 50,00 persen dan 13 orang atau 43,33 persen tamat SMA, sedangkan 2 orang atau 6,67 persen dari responden adalah Strata satu (S1).

\section{c. Jumlah Anggota Keluarga}

Jumlah anggota keluarga merupakan sumber tenaga kerja dalam keluarga sekaligus merupakan beban yang ditanggung oleh kepala keluarga.

Rata-rata tanggungan keluarga responden di Desa Lembar Selatan Kecamatan Lembar adalah 5 orang dengan kisaran 2 sampai 7 orang. Keadaan demikian berarti rata rata tanggungan keluarga tersebut digolongkan dalam keluarga sedang. Hal tersebut memberikan implikasi bahwa kebutuhan hidup rumah tangga responden berkaitan dengan jumlah anggota keluarga, artinya kebutuhan (pangan) akan lebih mudah terpenuhi jika jumlah anggota rumah tangga kecil.

\section{d. Pekerjaan Responden}

Jenis pekerjaan terbanyak yang ditekuni responden adalah Wiraswasta sebanyak 18 orang $(60 \%)$. Hal ini memang sebagian besar responden adalah pelaku usaha 
dibidang jasa usaha wisata, seperti warung makan, pemilik perahu dan tukang ojek. Selain itu 12 orang (40\%) responden bekerja sebagai staf desa, Pegawai Negeri Sipil (PNS) dan ada juga pekerja lepas dan buruh.

\section{Ketertsediaan Informasi}

\section{a. Jumlah dan tipe informasi}

Peranan teknologi informasi dan komunikasi dalam sektor pariwisata cukup besar dan penting, karena dengan adanya teknologi informasi dan komunikasi, memudahkan para wisatawan, untuk mengetahui lebih mudah tempat tempat wisata yang ada, sekalipun berada di daerah terpencil. Terkait dengan penelitian ini jumlah dan tipe informasi disajikan dalam tabel 1

Tabel 1. Jumlah dan Tipe informasi

\begin{tabular}{llll}
\hline No & Keterangan & Jumlah Responden (org) & Persentase (\%) \\
\hline 1 & Sangat Setuju & 8 & 26,67 \\
2 & Setuju & 18 & 60,00 \\
3 & Kurang Setuju & 3 & 10,00 \\
4 & Tidak setuju & 1 & 3.33 \\
5 & Sangat tidak setuju & 0 & 0 \\
& & 30 & 100 \\
\hline
\end{tabular}

Sumber : Data Primer diolah, 2020

Dari tabel kita dapat melihat bahwa jumlah dan tipe informasi kawasan wisata alam mangrove Lembar Selatan sudah cukup banyak. Sebagian besar responden setuju (60\%) dan ada 8 orang responden yang sangat setuju (100\%) bahwa jumlah dan tipe informasi sudah cukup diketahui. Selain itu ada juga yang tidak setujui sebanyak 1 orang

\section{b. Jumlah Tempat Yang Menyediakan Informasi Promosi}

Untuk mempromosikan suatu Lokasi wisata, tempat wisata atau obyek wisata harus diinformasikan melalui media massa, media eletronik, media social (Facebook, instagram, twiter), pamflet, spanduk, atau melalui media sosial lainnya. Ini dimaksudkan supaya lokasi wisata tersebut diketahui oleh semua orang agar mau berkunjung. Informasi juga bisa melalui dari mulut ke mulut, terutama dari orang yang pernah berkunjung duluan ke tempat wisata tersebut.

Berdasarkan tabel 2 dapat diketahui bahwa 90 persen dari responden sangat setuju dan setuju dengan adanya tempat informasi, karena menurut mereka penyebaran informasi tentang keberadaan suatu tempat sangat diperlukan, agar khalayak ramai tahu tentang lokasi wisata tersebut, kemudian berkunjung. Ada juga responden yang kurang setuju dan tidak setuju dengan adanya kegiatan informasi, dengan alasan, orang sudah pada tahu tentang keberadaan lokasi wisata mangrove ini, jadi tempat ini tidak perlu dipromosikan. 
Tabel 2. Jumlah Tempat Yang menyediakan Informasi

\begin{tabular}{llll}
\hline No & Keterangan & Jumlah Responden (org) & Persentase (\%) \\
\hline 1 & Sangat Setuju & 21 & 70,00 \\
2 & Setuju & 6 & 20,00 \\
3 & Kurang Setuju & 2 & 6,67 \\
4 & Tidak setuju & 1 & 3,33 \\
5 & Sangat tidak setuju & 0 & 0 \\
& Jumlah & 30 & 100 \\
\hline
\end{tabular}

Sumber : Data diolah Tahun 2020

Padahal suatu lokasi wisata perlu dipromosikan ke berbagai media agar

Akses informasi sangat penting bagi masyarakat luas dan luar tahu tentang keberadaan lokasi wisata tersebut.

Akses Pada informasi masyarakat, karena akses merupakan jalan masuknya suatu informasi agar diketahui oleh masyarakat local, domestic ataupun mancanegara.

Tabel 3. Banyak Masyarakat Yang mengakses Informasi Tentang Kawasan Wisata Mangrove di Lembar Selatan Lombok Barat.

\begin{tabular}{llll}
\hline No & Keterangan & Jumlah Responden (org) & Persentase (\%) \\
\hline $\mathbf{1}$ & Sangat Setuju & 9 & 30,00 \\
$\mathbf{2}$ & Setuju & 16 & 53,33 \\
$\mathbf{3}$ & Kurang Setuju & 4 & 13,33 \\
$\mathbf{4}$ & Tidak setuju & 1 & 3,33 \\
$\mathbf{5}$ & Sangat tidak setuju & 0 & 0 \\
\hline
\end{tabular}

\section{Sumber : Data diolah Tahun 2020}

Dari tabel 3 dapat lihat bahwa ada beberapa reaksi dari beberapa responden yang diwawancara sebagian besar sangat setuju dan setuju mengakses informasi tentang kawasan wisata mangrove Lembar Selatan. Sisanya mereka kurang setuju sebanyak $13,33 \%$ dan tidak setuju sebanyak 3,33\%, tidak mementingkan akses informasi, karena mereka berpikir yang penting ada wisatawan yang datang, bagi mereka ini sudah cukup.

Lembaga, Pemerintah dan Swasta yang Memberi Informasi Rencana Strategis

Pemerintah dan swasta juga berperan dalam mempromosikan lokasi wisata, ini erat kaitannya dengan adanya penerimaan pemerintah khususnya untuk Kas Desa sebagai salah satu sumber penerimaan desa dan PAD Kabupaten Lombok Barat. Dalam hal ini pemerintah harus aktif menyebarluaskan informasi, karena terkait dengan PAD dan ikon daerah yang bersangkutan.

Pihak swasta juga aktif mempromosikan ekowisata ini, karena berimbas pada jaringan usaha, mulai dari travel, penginapan dan lainnya. Bagaimana peran pemerinah dan swasta dalam memberikan informasi dapat dilihat pada tabel berikut ini. 
Tabel 4. Lembaga Pemerintah dan Swasta yang memberi informasi rencana strategis Pengembangan Ekowisata Mangrove di Lembar Selatan.

\begin{tabular}{|llll|}
\hline No & Keterangan & Jumlah Responden (org) & Persentase (\%) \\
\hline $\mathbf{1}$ & Sangat Setuju & 8 & 26,67 \\
$\mathbf{2}$ & Setuju & 18 & 60,00 \\
$\mathbf{3}$ & Kurang Setuju & 3 & 10,00 \\
$\mathbf{4}$ & Tidak setuju & 1 & 3,33 \\
$\mathbf{5}$ & Sangat tidak setuju & 0 & 0 \\
\hline & & 30 & 100 \\
\hline
\end{tabular}

\section{Sumber : Data diolah Tahun 2020}

Informasi rencana strategis kawasan ekowisata mangrove berdasarkan data pada tabel 4 tersebut, dapat diketahui bahwa sebagian besar sangat setuju (26,67\%) dan setuju (60\%). Mereka yang kurang setuju dan tidak setuju, ada kekhawatiran dari mereka akan berdampak pada lingkungan dan kehidupan sosial masyarakat, karena yang berkunjung ke ekowisata mangrove orang dari mana saja dengan membawa pola dan kebiasaan yang mungkin bertentangan dengan kehidupan masyarakat setempat.

Sudah ada rencana dari pemerintah Kabupaten Lombok Barat, melalui Dinas Pariwisata untuk mengembangkan ekowisata mangrove ini kearah yang wisata multifungsi (dalam satu paket), wisatawan bukan hanya menikmati pemandangan alam saja, tapi juga sambil berolahraga, bersepeda santai bersama keluarga, senam dan menikmati aneka kuliner khususnya makanan khas sasak. Nanti ada rencana paket wisatawan yang langsung mengajak wisatawan memasak kemudian menyajikan sendiri menu pilihannya.

Rencana pengembangan ekowisata mangrove ini seharusnya sudah mulai dikerjakan Tahun 2020, tapi karena adanya Pandemi, rencana ini tertunda dan semoga terwujud pada Tahun 2021.
Model Partisipasi Masyarakat Dalam Ekowisata Mangrove

Partisipasi masyarakat dalam pengembangan desa wisata pada prinsipnya adalah partisipasi dalam mengelola sumber daya. Oleh karena itu, perlu dirumuskan model yang relevan dalam pelaksanaan program tersebut. Model dipandang sebagai acuan dalam merencanakan, mengimplementasi, dan mengevaluasi program. Sebagai sebuah pendekatan, model yang dirumuskan harus merepresentasikan partisipasi masyarakat dalam setiap aspeknya.

Harapan masyarakat Desa Lembar Selatan Kecamatann Lembar dalam pengembangan Ekowisata mangrove ke depan adalah:

1. Pengembangan ekowisata mangrove harus berpedoman pada potensi masyarakat dan lingkungan;

2. Masyarakat harus terlibat penuh dalam pengembangan Ekowisata;

3. Menghargai hak-hak masyarakat lokal;

4. Memperhatikan kelestarian lingkungan yang ada di sekitar Desa Lembar Selatan, Kecamatan Lembar;

5. Pemanfaatan rumah penduduk untuk akomodasi wisatawan; dan

6. Ada kelembagaan otonom dan mandiri yang dibentuk oleh masyarakat lokal dibawah tanggung jawab desa adat. Ada jaminan bahwa masyarakat harus 
terlibat di dalamnya agar program pengembangan desa wisata berjalan sesuai dengan kebutuhan masyarakat.

Untuk menjamin hal itu dirumuskan halhal sebagai berikut:

1. Pengembangan Ekowisata Desa Lembar Selatan harus berpedomanan pada kebudayaan lokal masyarakat;

2. Masyarakat lokal menjadi sentral dan menjadikan subjek dari semua proses pengembangan ekowisata. Dengan menempatkan masyarakat sebagai sentral diharapkan partisipasi masyarakat sebagai pemilik sumber daya pariwisata akan terdorong dan mampu mensejahterakan masyarakat lokal;

3. Pengembangan desa wisata membutuhkan adanya kemitraan yang solid antara tiga unsur utama, yaitu pemerintah, swasta, dan lembaga. Dalam hal ini masyarakat lokal menjadi pemangku kepentingan dari kerja sama tersebut;

4. Ketiga pemangku kepentingan tersebut berada pada posisi yang sejajar dalam melakukan kerja sama serta saling menghormati;

5. Perlu dibentuk badan pengelola yang otonom dan mandiri, yang saling berinteraksi, memberikan umpan balik pelaksanaan untuk mengoreksi diri pada setiap jenjang organisasi;

6. Keputusan dan inisiatif untuk memenuhi kebutuhan masyarakat lokal dibuat ditingkat lokal oleh warga masyarakat yang memiliki identitas yang diakui peranannya sebagai partisipan dalam proses pengambilan keputusan; dan

7. Fokus utama pengembangan ekowisata adalah memperkuat kemampuan masyarakat lokal dalam mengarahkan dan mengatasi aset-aset yang ada pada masyarakat lokal untuk memenuhi kebutuhannya.

Pelaksanaan hubungan antar pemangku kepentingan tersebut terarah, peran dan tanggung jawab masing-masing harus jelas. Peran dan kewenangan masingmasing pemangku kepentingan sebagai berikut:

Peran dan Kewenangan Pemerintah, yaitu; (1) melakukan pembinaan kualitas produk dan kuliner khas desa sebagai unsur kenangan wisata; (2) melakukan penataan dan konservasi lingkungan fisik kawasan yang menjadi ciri khas ekowisata; (3) melakukan perbaikan/pengadaan infrastruktur persampahan dan sanitasi; (4) melakukan gerakan masyarakat untuk mewujudkan sapta pesona; (5) melakukan pembuatan informasi dan fasilitas kepariwisataan; (6) melakukan perbaikan/ peningkatan kualitas ruang publik, dan (7) dukungan pemberdayaan terhadap kelompok sadar wisata (Pokdarwis) dalam pelestarian lingkungan pariwisata (kawasan Hutan, dan sawah).

Peran dan Kewenangan Swasta (Investor, LSM, pelaku pariwisata lainnya), yaitu; (1) melakukan promosi terintegrasi antar pengelola objek wisata untuk menggerakkan kunjungan wisatawan antar objek wisata; (2) pembuatan dan pemasaran paket-paket wisata yang kompetitif yang terjangkau oleh masyarakat; (3) pelatihan kewirausahaan, pelatihan keterampilan individual terkait usaha di bidang pariwisata (pelatihan bahasa Inggris; (4) pengembangan kelompok usaha bersama masyarakat; dan (5) menjalankan bisnis restoran, suvenir, dan lain- lain.

Peran masyarakat Lokal, yaitu; (1) menyediakan sebagian besar atraksi 
sekaligus menentukan kualitas produk wisata. Pengelolaan lahan pertanian secara tradisional, upacara adat, kerajinan tangan dan kebersihan; (2) pelaku budaya, misalnya kesenian yang menjadi salah satu daya tarik wisata; dan (3) penyedia akomodasi dan jasa pemandu wisata, penyediaan tenaga kerja, produk makanan khas, kerajinan lokal, kesenian lokal, dan sebagainya.

Peran dan Kewenangan Badan Pengelola, yaitu; (1) badan pengelola sebagai pengelola utama dan pengarah dalam perlindungan, perawatan, pelestarian guna mempertahankan fungsinya sebagai ekowisata; (2) melakukan pengaturan yang diperlukan dalam rangka pengembangan ekowisata mangrove Lembar; menyediakan dan mengoperasikan segala fasilitas untuk menunjang kegiatan usaha; (4) Menetapkan dan memungut biaya/retribusi dan pungutan lainnya atas pemanfaatan fasilitas yang tersedia dan hasil seluruhnya merupakan pendapatan badan pengelola; (5) melakukan perencanaan dalam bidang pengembangan atraksi/produk wisata, pengembangan fasilitas wisata; (6) melakukan pengorganisasian dalam bidang penguatan dan pengembangan kelembagaan; (7) melakukan pengarahan untuk peningkatan kompetensi pengelola objek wisata agar sesuai dengan tujuan pengembangan desa wisata yang berkelanjutan; dan (8) melakukan evaluasi dan pengawasan terhadap aktivitas kepariwisataan agar tercapainya tujuan pengembangan desa wisata yang berkelanjutan.

\section{KESIMPULAN DAN SARAN}

\section{Kesimpulan}

1. Masyarakat sudah banyak yang berpartisi dalam ekowisata Lembar selatan, dengan membuka usaha kuliner (makanan khas Sasak), menyediakan sampan/perahu untuk mengelilingi lokasi mangrove, ada jasa parkir yang melibatkan masyarakat, khususnya sebagai tukang parkir dan menjual/memeriksa tiket masuk.

2. Dalam penyebaran informasi, sudah dilakukan oleh para pemudanya yang tergabung dalam Karang Taruna Desa Lembar Selatan.

3. Model partisipasi masyarakat dalam mengelola informasi harus ada kemauan secara bersama sama (Masyarakat, aparat desa, pemerintah dan swasta) dalam mengembangkan ekowisata mangrove Lembar Selatan secara signifikan.

\section{Saran}

1. Rencana pengembangan dan renovasi ekowisata mangrove Desa Lembar Selatan semoga berjalan sesuai dengan yang diharapkan.

2. Masyarakat Kecamatan Lembar umumnya dan masyarakat Desa Lembar Selatan khususnya, harus mempunyai kemauan yang serius dan konsisten dalam memelihara lingkungan ekowisata, agar tetap berlanjutan.

3. Masyarakat perlu diajak untuk mendesain sendiri model pariwisata yang akan dikembangkan, karena mereka yang tau apa yang baik dan yang cocok untuk mereka lakukan.

4. Perlu dibuatkan Awig-awig desa tentang menjaga obyek wisata (Destinasi) dan pemanfaatan tanah untuk membuka usaha. 


\section{DAFTAR PUSTAKA}

Ade Jafar Sidiq, dkk. 2016. Pengembangan Desa Wisata Berbasis Partisipasi Masyarakat Lokal di Desa Wisata Linggarjati Kuningan Jawa Barat. Prosiding, Riset dan PKM Volume 4 No 1.

Arief Faizal Rahman. 2014. Model Partisipasi Masyarakat Daklam Pariwisata di Pantai Swarna Kabupaten Lebak, Provinsi Banten. Universitas Paramadina Jakarta.

Bappeda, 2018, Rencana Tata Ruang Wilayah Kabupaten Lombok Barat, Kantor Bappeda Kabupaten Lombok Barat Tahun 2019.

Dinas Pariwisata Kabupaten Lombok Barat 2019, Rencana Induk Pengembangan Pariwisata Daerah (RIPPDA) Kabupaten Lombok Barat Kabupaten Lombok Barat dalam Angka Tahun 2019. Kantor Badan Pusat Statistik Provinsi Nusa Tenggara Barat, 2019.

Kecamatan Lembar dalam Angka Tahun 2019. Kantor Badan Pusat Statistik Provinsi NTB, 2018.

Laksmi Puja Sukma. 2018. Persepsi Masyarakat Terhadap Ekosistem Hutan Mangrove Di Kawasan Kuala Langsa, Kecamatan Langsa Barat Kota Langsa, Universitas Syiahkuala Banda Aceh.

Marpaung, H. 2000. Pengetahuan Kepariwisataan, Alphabeta, Bandung.

Maria Grace Lawe Siu, Siti Amanah, Nyoto Santoso. 2020. Partisipasi Masyarakat Lokal Dalam

Pengelolaan Ekowisata Mangrove Di Kelurahan Oesapa Barat Kota Kupang. Jurnal Ilmu Kehutanan Tengkawang. Fakultas Kehutanan Universitas Tanjungpura. Vol 10 no. 1

Muh. Amran Amir 2017. Analisis SWOT.

(http://media-amran.blogspot.com/2010/08/analisis-swot.html, diakses pada 24 Oktober 2017)

Pendit, N. S. 1994. Ilmu Pariwisata Sebuah Pengantar Perdana. Pradnya Paramitha Jakarta. Suara Merdeka, 11 Januari 2015. Potensi Agrowisata dan Strategi Pengembangan Agrowisata Titi Yuniarti dkk. 2018. Strategi Pengembangan Potensi Kecamatan Gangga Sebagai Kawasan Agrowisata Di Kab Lombok Utara. FEB Unram 2018.

2019. Partisipasi Masyarakat Lokal dalam Pengembangan Agrowisata di Kecamatan Gangga Kabupaten Lombok Utara". FEB Unram 2019

UU No 32 Tahun 2009 tentang Perlindungan dan Pengelolaan Lingkungan Hidup. KLH RI, 2013 Yoeti, A. O. 1982. Pengantar Kepariwisataan, Sebuah Pengantar Perdana, Pradya Paramitha, Bandung.

Yusti Martena Afrit Anova. 2013. Keanekaragaman Mangrove Di Pantai Kecamatan Panggungrejo Kota Pasuruan. Fakultas Sains Dan Teknologi Universitas Islam Negeri Maulana Malik Ibrahim. Malang. 